\title{
Atmospheres of retail and the asceticism of civilized consumption
}

\author{
Andrea Mubi Brighenti ${ }^{1}$ and Mattias Kärrholm ${ }^{2}$ \\ ${ }^{1}$ Department of Sociology and Social Research, University of Trento, Trento, Italy \\ ${ }^{2}$ Department of Architecture and the Built Environment, Lund University, Lund, Sweden
}

Correspondence: Andrea Mubi Brighenti (andrea.brighenti@unitn.it)

Received: 2 November 2017 - Revised: 8 March 2018 - Accepted: 22 May 2018 - Published: 3 July 2018

\begin{abstract}
During recent decades, consumption-oriented spaces of comfort and hospitality have proliferated - including, for instance, lounge shopping malls, food court plazas, spas, entertainment retail, visitor centres, and the development of ever larger pedestrian precincts. In this article we explore shopping malls as capitalist "domes" in Sloterdijk's sense. We observe atmospheric production, atmospheric management and atmospheric culture (which we propose to call atmoculture) inside such domes. Processes of retailization and mallification whereby shopping malls and retail spaces absorb increasing economic and societal energies - can be regarded as correlative to the rise of an atmoculture of civilized consumption. Such atmoculture is visible for instance in stress-avoidance strategies and the production of a pleasurable experience in consumption-oriented public zones. The design of contemporary retail spaces seems to pivot around specific atmospheric strategies developed to promote and sustain civilized consumption. In this piece, we describe four different strategies of atmospheric production, identifying their possible shortcomings and failings. Finally, we advance the hypothesis that the atmospheric production of retail can also be analyzed with reference to Sloterdijk's theorization of asceticism as self-disciplination.
\end{abstract}

\section{Introduction}

In his trilogy Sphären (1998-2004) (Sloterdijk, 2011, 2014, 2016), Peter Sloterdijk describes capitalist modernity as engaged in a constant production of "domes", large structured spheres in whose atmosphere purposeful social activities can be carried out and thrive. Outlining the modern technological history of bodily and societal containments, Sloterdijk highlights the historically important roles of hothouses, air conditioning, as well as, a contrario, fumigation, gas attacks, etc. ${ }^{1}$ On the same account, he also depicts the building types of the apartment house and the sport stadium as "the two most successful architectural innovations of the twentieth century" (Sloterdijk, 2016:529): the apartment house works as a stackable spatial crystal, a "rigid foam body" for societal development (Sloterdijk, 2016:537), whereas the sports stadium

\footnotetext{
${ }^{1}$ From this perspective, war can be regarded as simultaneously the destruction of atmosphere and, correlatively, the instalment of a peculiar atmosphere.
}

embodies the quintessential space for modern mass meetings and mass culture. Atmospheric production here seems essential in both undertakings.

In general, as recognized by both phenomenological literature (Böhme, 1993; Runkel, 2016) and affect theorists (Anderson, 2009), atmospheres imply collective and individual sensory experiences and moods related to the peculiar aspects of light, air, scent, comfort, etc. These aspects cannot be easily reduced to simple metrical dimensions. They come in different scales or level of importance, and "encompass mundane interventions such as the dimming of lights as well as threats of violence or impending meteorological events" (Gandy, 2017:370). Atmospheres might thus have major social and political impact, yet they are often fuzzy and notoriously hard to pinpoint. Atmospheres are non-deterministic and relational: they are produced through relations between a wide array of entities, and their meaning differ from moment to moment, yet they are inescapably there. For Sloterdijk, living in the word always includes living in atmospheres in 
the form of sheltering domes, homes, bubbles, etc. (Thrift, 2009:124). Atmospheres are thus intimately connected with architectures and non-human bodies, and as such they are inherent products as well as producers of modern society. Architectural modernism is related to atmospheres in terms of comfort design and in-door climates in the new building types of the 19th century and onwards (Sloterdijk, 2005, 2011) - in short, atmospheres could be seen as part and parcel of the modernist project of appropriating and territorialising the world (Serres, 1995).

If atmospheres are key to analyse the modern socio-spatial set up, then it could perhaps also be claimed that our epoch is contradistinguished by the rise of atmoculture, that is, a set of expectations and requirements about the production and maintenance of given atmospheres to accompany or guide our urban life (Brighenti and Pavoni, 2017). Atmoculture can be characterized as a widespread process that places atmospheres at the centre and pivot of many urban stakes. Today, atmospheres are seen as a valid architectural design assignment, much in the same way as facades or spatial plans. The designing of specific moods or characters, is of course nothing new, and has been an important part of architectural design for centuries (Gandy, 2017:365; Forty, 2000). However, during the last decades the topic has been more explicitly addressed as an important architectural and aesthetical concept (see Bille et al., 2015 for a good introduction). In terms of retail design and branding, Kotler (1973) set an early example with his article on atmospherics as a marketing tool, but in terms of a wider discussion of aesthetics, the work of the German philosopher Gernot Böhme has probably been the most influential (Böhme, 1993, 1995); indeed, Böhme had an early impact on architectural research (Albertsen, 1999) and has also inspired internationally well-known architects such as Peter Zumthor (2006; see also Borch, 2014:7).

Atmospheres are becoming an increasingly salient and intentional part of the built environment. In Sloterdijk's terminology, we could speak of an explicitation or explication of the atmosphere. The expressive and affective components of atmospheres are crucial, since atmospheres do not just fill a space, they also play an important part in spatial and material productions (Anderson, 2009:80). However, the crucial point is that, despite their pervasiveness, atmospheres remain evanescent objects; they are produced as middles and often escape univocal categorizations - they are hybrid mixtures of spatial and material, material and social, individual and collective, objective and subjective. Atmospheres are both part of an experience and of the experienced, a relation whose actors are indeterminable, and/or yet to be defined.

Focusing on the case of shopping malls, we argue that the design and staging of atmospheres at malls and other retail spaces can be seen as connected to the rise of a civilized consumption and even asceticism as a form of disciplination. However, it should be emphasized that this is not a research about shopping malls, rather, malls are discussed here as an extended example to advance the theorization of contempo- rary atmoculture and its territorializations. It is thus important to note that we are interested in generating and developing a specific hypothesis, and that our article should be seen as a theoretical think piece that hopefully can prepare for further empirical research, rather than a proper empirical study itself. In the text we review various strategies of atmospheric production and look at how the engineering of atmospheres is enacted. How are individuals scripted, engaged and activated in the atmospheric planning of these architectures? We approach shopping malls and related building types as instances of the development of what Sloterdijk calls a "space interior of capital" (Sloterdijk, 2013a). From this perspective, malls are arguably one of the most notable instances of deliberate atmospheric management in the contemporary world. We also characterize the rise of atmoculture as correlative to the unfolding of the technophysics of consumer domes. Atmospheric engineering alone cannot, in our view, explain the success of contemporary retail. Culturally widespread attitudes are a necessary component of the social and economic success of places like malls. Indeed, how and why can malls become desirable on a mass scale? To answer this question, we also need to take into account the fact that the design of contemporary retail spaces is aimed to facilitate and sustain an atmocultural attitude of "civilized consumption" (Ranasinghe, 2011). To make sense of such attitude, we highlight the relation between the condition of the consumer and what Sloterdijk (2013b), in his exegesis of Nietzsche and Rilke, has called the "ascetic imperative". Throughout his oeuvre, Sloterdijk has linked atmospheres to the larger process of anthropotechnics, that is, the range of technologies aimed at the production of humanity itself. Such a view seems to be informed by a Nietzschean insight about humankind as the species that still has yet to become human. ${ }^{2}$ In this framework, modernity is intimately tied to "the emergence of a general training consciousness" (Sloterdijk, 2013b:55), and each individual subject is conceived of as structured by an inner vertical axis determining tendencies towards, alternatively, better and worse deeds, instincts and performances. From this point of view, asceticism is nothing more than $e x$ ercise (askesis). For Sloterdijk, the modern human subject cannot content himself with existing, s/he must always improve her/himself, always set new standards of assessment. How does the - first religious, then Romantic - discourse of self-transcendence and ascetic self-improvement get translated into the consumer's experience and with which effects?

The article is structured into five sections. After this introduction, we review the state of research on atmospheres in the context of retail and shopping malls. In the third section, we zoom in onto various factors and functors of atmospheric production, singling out four basic atmospheric strategies which we call, "immediate responsiveness", "in-

\footnotetext{
2 “... and then the clouds break, and we see how, with the rest of nature, we are straining towards man, as towards something that stands high above us" (Nietzsche, 1876: Sect. III:5).
} 
tensity through variation", "mediating gestures" and "dangerous proximities". The fourth section then examines how the spatial aspects of atmospheric production connect to the notion of civilized consumption or, more specifically, to an atmoculture of training, practicing and improving through consumption, i.e. a type of civilized consumption that - despite all appearances - is "ascetic" at its core. In the fifth and final section we conclude the discussion and make some suggestions to guide future research.

\section{Retail and atmospheric production}

During recent decades, we have witnessed the proliferation of consumption-oriented spaces of comfort and hospitality (Bell, 2007) - including, for instance, lounge shopping malls, food court plazas, spas, entertainment retail, visitor centres and the development of ever larger pedestrian precincts (Kärrholm, 2008). In European countries such as France and Sweden we saw large shopping mall structures already developing in the 1960s and 1970s. Netherlands (Rotterdam) and Denmark (Copenhagen) set early models for the pedestrianization of old inner city centres that were conducive to new ways of retail and consumption in public space. Today some of these spaces have bloomed into (sometimes successful, sometime struggling) large and specialized retail areas (Gehl and Gemzöe, 1996; Monheim, 2003; Kärrholm, 2012). Although, Crawford (before Sloterdijk) noted how retail already started to produce its "pleasure domes" with the department stores of the 19th century (Crawford, 1992), it seems fair to say that retail spaces now can be found been found in larger and larger domes. From the 1970s onwards, atmospheres and atmospherics have become an increasingly important and studied factor in efforts of affecting the mood of consumers (Turley and Milliman, 2000; Vernet and de Wit, 2007; Biehl-Missal and Saren, 2012; Healy, 2014, cf. Julmi, 2016). ${ }^{3}$ The development of retail spaces can also be seen in parallel to a recent interest in the constant branding (Klingmann, 2007), eventalization (Plöger, 2010) and spectacularization (Degen and Rose, 2012) of the city, as well as in the sensory experience of the urban citizen in general.

The social, economic and environmental impact of largescale retail outlets on existing urban systems has been tackled extensively in recent literature. Retail and consumption have been explored as major components of social life in the contemporary city (Miles and Miles, 2004; Gibbs, 2012). Shopping centres located in suburban areas and accessible mainly by private transport have acquired increasing significance, turning into new hubs of social life for large population shares (Shields, 2003; Zukin, 2004). The notions of

\footnotetext{
${ }^{3}$ As atmospheres of retail spaces and shopping malls (Michon et al., 2005) have become more and more elaborated and salient, there also seems to be a small but increasing number of studies on the subject that come from outside marketing research, for example from the field of aesthetics (Hasse, 2004; Kazig, 2007).
}

urban renewal, smart city and urban resilience have likewise provided theoretical lenses to understand the process of mallification, i.e. the diffusion of increasingly large shopping mall compounds (Staeheli and Mitchell, 2006; Ozuduru and Guldmann, 2013). Not least, the new retail spaces have also fostered forms of veritable shopping tourism (Rabbiosi, 2011).

The level of subjective experience in retail spaces is important. "Civilized consumption" is the expression that best captures the vision reclaimed in particular by developers and the business sector, premised on the belief that optimum consumption necessitates an accordingly "civilized" public behaviour (Ranasinghe, 2011). Of course, what "civilized" means is controversial. Critical scholars have highlighted how, at the level of daily interaction, the requirements of civilized consumption may impinge on free personal mobility and may be conducive to new inequalities and discrimination (Staeheli and Mitchell, 2006; Cohen, 2014). However, civilized consumption is not simply sustained by the most powerful economic actors; it is likewise not simply imposed hierarchically and by design. On the contrary, it can be observed as an interaction format that is mobilized essentially in a coarchic way by the involved actors in their everyday encounters. From this perspective, the contemporary preoccupations with the design of comfortable atmospheres and spaces of hospitality can be meaningfully compared with earlier theorizations in urban theory about the inherently threatening and excessive nature of urban space. Early social theorists held a vision of urban space as the space of pure modernity - where pure also meant bare modernity. The city was conceptualized in terms of a metropolis bearing shocking effects on the nervous system of its inhabitants. Simmel (1903) for instance, insisted on the nexus between sensorial stimulation and psychic (hyper-)activity. In his view, the maintenance of personality entails a constant work of adjustment to external forces of the natural and human environment. Urbanites are affected by differences and adjust to circumstances by processing the differences that exist between various incoming stimulations. In the flair of cities, Simmel observed, all sorts of events surrounding the individual consume a quota of their consciousness. In reaction, urbanites retreat from urban hyperaesthesia into a special type of anaesthesia; they intellectualize social life using their brain as a protective organ that cools off the heat of affective stimulations. Urban life was thus described as a life of the brain, not one of the heart, a life of rational, calculative control over emotions, and even, a cover-up of emotions. But, how does this early analysis sit with the contemporary design emphasis on pleasurable affects and sensations that are supposed to sustain and foster consumption?

In the following, we develop a discussion of how territories of shopping are co-produced through atmospheres. The territorialization of urban and sub-urban areas into an amalgam of connected and coherent retail spaces - a process we have called retailization (Kärrholm, 2012) - does 
not work with regulations and built borders alone, but also with ambient design and an "ambient power of seduction" (Allen, 2006). According to the French phenomenologist Mikel Dufrenne (1953), atmospheres are extremely mobile and impalpable facts of perception and affection, always becoming, and extremely sensible to the apparition of new bodies in a place. Nonetheless, as remarked by Böhme (1993:114), atmospheres seem to "fill the space with a certain tone of feeling like a haze"; in other words, they have a tendency to occupy and even "colonize" space. This fact raises a problem of limits and thresholds: where does an atmosphere begin and where does it end? How can it be circumscribed? Philippopoulos-Mihalopoulos (2015) has argued that, in order to understand atmospheres we must begin from the middle, from their milieu. Not by chance contemporary retail spaces are configured as open environments: instead of being segmented into coherent areas by clear threshold lines, the new spaces of civilized consumption appear to be increasingly smooth and infused in the everyday urban landscape, as well as within each other. Such open environments have proven extremely successful, not only commercially, but also and especially in their capacity to attract people. Their social-spatial configurations have managed to appear desirable and pleasurable mainly thanks to their atmospheric qualities. Even though the border of a territory might be clearly demarcated, materialized and sanctioned by law, its spatial extent and spatial impact shift according to the unfolding situation. Atmospheric engineering also insists on gaps of imperfection and dissonance, "creating a space of uncanny disjunction, an interval that invites the participating bodies to follow along" (Philippopoulos-Mihalopoulos, 2015:93), because imperfections create invitations to new actors or new rhythms to be induced. Atmospheres thus have fuzzy borders, yet somehow achieve the task of "partitioning air" (Philippopoulos-Mihalopoulos, 2016) - something that is logically impossible, yet anthropologically indispensable, given that humans rely on such partitions for the provision of a sense of existential security.

From both the subjective and objective perspectives, atmospheres thus take an active part in the production of the multiple and apparently permeable borders that circumscribe and/or run across everyday urban territories, where degrees of permeability are correlative to social status, power, as well as situational contingencies. Atmospheres work with processes of territorialization, with urban imitations and with the catching and repetition of rhythms (Borch, 2014; Philippopoulos-Mihalopoulos, 2015). Let us try to zoom in onto the ways in which these elements can be concerted.

\section{At the mall: factors and functors of atmospheric production}

Contemporary retail spaces have been produced within the mould of modernist heritage. Commodities of the Western world are often interiorized and put on visual display (in shops as well as online), rather than approached head-on in the streets, and even though some retail spaces have changed into new types or subtypes, the basic types of malls, arcades, market halls (big boxes), stores, etc., largely persist. Brick and mortar retail is still aiming for comfortable atmospheres (Sharma and Stafford, 2000; Turley and Milliman, 2000), for civilized consumption and for producing spaces with certain expected behaviours. However, mall-goers or shoppers are not a homogeneous or totally obedient group. In fact, behaviour in shopping environments is very similar to behaviour found in other public settings and in the public domain at large. Shopping environments are stages for similar meanings and practices as public settings, and the transposition of these are quite common (Stillerman and Salcedo, 2012:318). The figure of the civilized consumer is thus quite closely related to that of the civilized citizen; it is a role that, perhaps spurred by a specific atmosphere or affordance, might come and go from moment to moment, yet it remains a certain consistency over time, forming as it were a traceable narrative. Critique of mallification has extensively argued that shopping malls tend to attract white middle class car owners more than anything else (Lofland, 1998; Staeheli and Mitchell, 2006). Although there is a certain truth to this, it is just a part of the picture. In fact, the early critique on shopping malls emanating from the US (Crawford, 1992; Goss, 1993; Lofland, 1998) has, during the last decades, been complemented with ethnographic studies from all over the world, showing malls to be quite complex places that host quite heterogeneous populations. Here we suggest five different points to consider: first, shopping malls are not only used by car-owners. Looking at pedestrian precincts and shopping malls in European cities these are not always (but often) well connected with public transport. Second, shopping malls are not just for the middle class. An increasing number of studies in developing countries show that malls are quite often located in the vicinity of poor communities and existing markets. In more affluent countries we also see different strategies, which enable poorer segments of the population to use the malls (Stillerman and Salcedo, 2012). Third, shopping malls are different from each other, and individuals use different strategies and tactics as they make use of malls and other retail spaces during their routes in the city (Brembeck et al., 2015). Malls and other shopping environments are individual places and, as people live their lives in urban regions and landscapes rather than inside the boundaries of a town, these places are increasingly part of the urban fabric and the everyday set of urban life. Fourth, shopping malls can be places of emancipations. In developing countries like Turkey, for instance, they have been described as providing women "freedom from the problem of the street" (Erkip, 2005:102) in a similar way to the French department stores in the 19th century (Wolff, 1985:44). Fifth and finally, shoppers disobey and resist expected behaviours. An increasingly common example is people who try out clothes, look at 


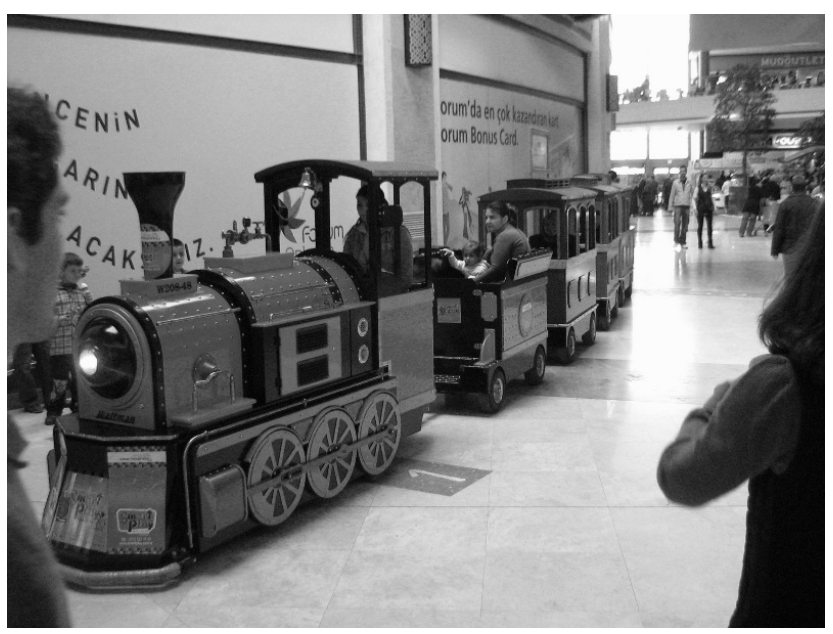

Figure 1. Train ride at the Forum Ankara Outlet, Turkey (photo by author).

books, etc., in shops only to order them later over the internet for a cheaper price. There is also more active resistance with ongoing battles between mall management and disobeying visitors (Fiske, 1989), which have caused malls to seal off certain entrances (Dovey, 1999:135 pp.), reduce seating (Stillerman and Salcedo, 2012:327) or make similar adjustments.

This said, the increasing focus on atmospheric design at retail spaces has become part and parcel of a management of activities aiming to produce a "world consumer", as for example can be seen in the idea of the global yet still fairly exclusive consumer culture of airports. Although all lived environments are bound to be complex, there might be reasons to investigate the recent strategies of activation that come with the recent focus on atmospheric retail design. In this context, atmospheres work as inscription devices (Akrich, 1992) of disciplined activation aimed to shape not only a civilized citizen, but also more specifically a civilized consumer. Specifically, the consumer needs to be pacified (tamed) but simultaneously also activated (spurred). Thus, the shopping mall atmosphere needs not to be in opposition to a complexity of usages. On the contrary, it might draw on this complexity and activate it in search for new potential opportunities (and in the end, of course, profit). Below we exemplify how this production of the civilized - pacified yet activated - consumer can be accomplished by discussing four different factors: short rather than long moments of responsivity, intensity rather than difference, insistence of mediated atmospheres, and the production of dangerous proximities. ${ }^{4}$

\footnotetext{
${ }^{4}$ The findings are based in literature studies, but also to a lesser extent in field trips and empirical material produced in connection to other earlier studies made by the authors that took place between 2006 and 2011 (Kärrholm, 2012). No empirical material has been produced specifically in connection to this article, except for a short observation one-day visit to Emporia, Malmö, in June 2017.
}

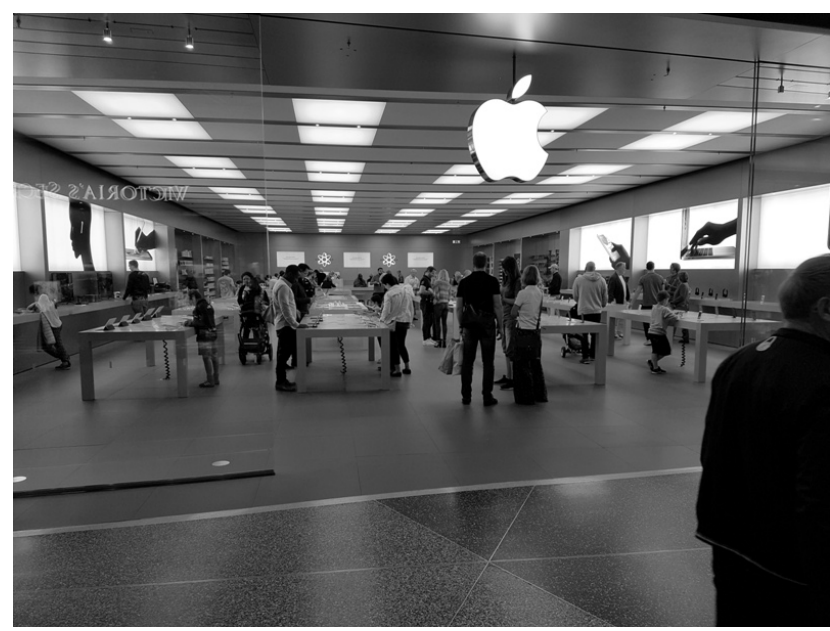

Figure 2. Apple store at Emporia, Malmö (photo by author).

\section{(a) Immediate responsiveness - short is sweet}

Retail environments often activate customers into taking part of a brand, a special offer, a new product's launch, seasonal sales, or just any kind of event or special offer (see Figs. 1 and 2). According to Asplund (1987), humans, animals and things can show different tendencies to respond to the action of another, they can (in different degrees) answer back in a "sociable" way. Responsiveness (from the Latin responděo$\bar{e} r e$, to answer) plays an important role in social life. It is very hard for a human not to answer back to another human, but responsiveness can also be found in objects, such as kites and swings. If we take this insight further, we can also see how environments and even atmospheres respond more or less to our activities (Wikström, 2009; Nilsson, 2010:60 pp.; Philippopoulos-Mihalopoulos, 2013); shopping environments are turned into sensible or even sentient environments capable of being responsive to the social life unfolding inside them - that is, capable of being social themselves. The escalator and the automatic door that move as you approach them are both early examples of this.

Responsiveness can be described as an affective relationship, a negotiation of at least two parts, where both are marked by the event of their interaction for a protracted lapse of time. In retail environments, responsivity can be short, but sweet. These places afford to be smelled, tasted, clicked, swiped, scanned, photographed, etc., but they seldom invite us to long negotiations, like those in traditional bazaars (Escher, 2008) and old village stores. There must be room for next person to try the free taste sample, sign in as club member, etc. Famously, Gibson (1986) described an "affordance" as what the environment offers or furnishes. Responsiveness is related to affordance, yet it does not say so much about what the environment affords me, rather, what I can afford the environment - I can afford it to be inscribed, to be transformed, etc. This means that responsiveness involves leav- 


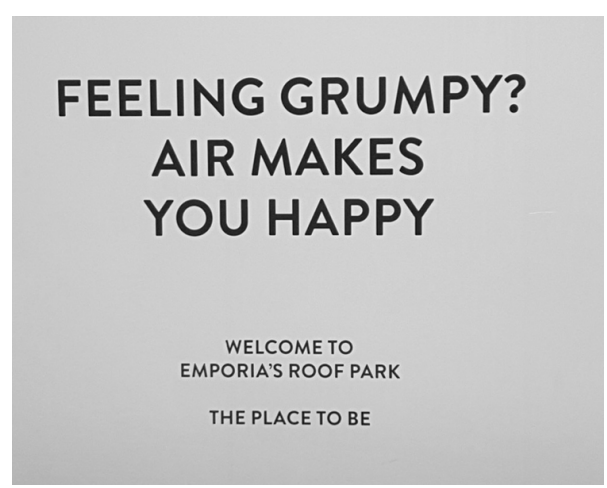

Figure 3. Advertising the roof garden at Emporia, Malmö (photo by author).

ing a mark: the kite to change its direction, the wall to get inscribed and the doors to open. Consumption spaces seem to be characterized by different (albeit often themed) affordances, and a quick and rhythmic pace of responsivity. The environment responds to my actions, and my actions end up guided by the accurate staging: even the pyramid of apples has a small hole to direct my moving hand. My mark on this pile of apples is directed, restricted, anonymous and soon wiped away by others. I can leave a mark, but only as long as it can be wiped away in the next moment. There is an atmosphere of branded tolerance that engages us to interact, but only until the next consumer in line comes along.

\section{(b) Intensity through variation - stay in the game}

In 2016 Apple chose to no longer chain their iPads on display in Apple stores, but allowed the customers to hold them freely, put them into pockets and walk around with them in the store. ${ }^{5}$ Although enabling the potential customer to interact with the iPads may in the first place be seen as a way of temporarily increasing responsiveness, the unchaining of these iPads answered to another strategy as well. The aim was to allow for a certain amount of freedom in the interaction, i.e. for an intensity with variety. Shopping malls often bet on intensity rather than on categorical differences and ruptures, that is, on intense sensory stimulation rather than on a series of disruptive sensory stimulations. In the traditional European city, the relation between the shop and the street is important, the ability to step outside with a screaming kid or a phone call, to "take it outside" is an option sometimes preferred. At the mall, this possibility is not so obvious because its space is guarded by similar rules as shops themselves. You would have to leave the area altogether. This results in people dwelling in the same atmosphere but with different "tonalities" (Albertsen, 2012:70), which can be set by the seamless

\footnotetext{
${ }^{5}$ Information retrieved from https://www.macrumors.com/2016/ 10/14/apple-stores-removing-iphone-security-tethers/ (last access: 30 September 2017).
}

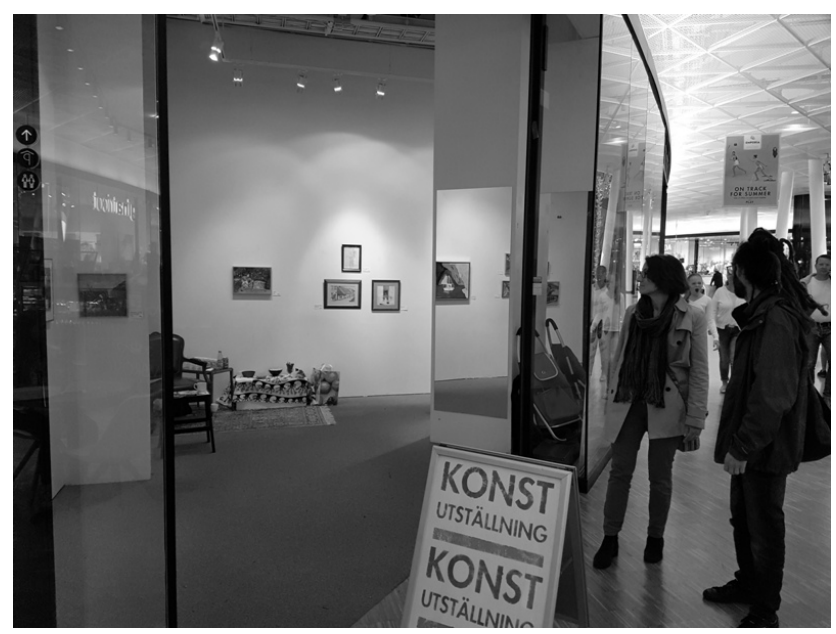

Figure 4. Temporary art exhibition at Emporia, Malmö (photo by author).

change of tone in an experienced atmosphere. ${ }^{6}$ Atmospheres are salient, yet their borders are vague and elastic both in time and space, and they can have a sticky quality: they keep on lingering for a while. Thresholds are erased, or rather, pushed further out, as retail areas grow bigger. Where does this pushing out end? Traditionally, the different territories of the mall (in this case, individual stores and passage ways within the mall) have been flooded with the same or similar atmospheric characteristics; the atmosphere of the mall is partly set by a few very deliberately designed actors such as muzak, wide aisles, strong lights and logo signs. This has now increasingly been complemented by another strategy: the production of niches, or a haven with other smells and sounds but still with an atmosphere associable to the mall. One way to describe this would be to say that malls are deliberately expanding the repertoire of associable entities, investing in longer durations of intensity through the variety of a theme. One example is the rooftop garden, which grants an exit for nauseated consumers (Fig. 3). Dropping out of the designed atmosphere may be an important strategy to sustain the atmosphere itself - something Sloterdijk does not seem to have considered given that, in his theory, capitalism works only by ingesting increasing amounts of stuff into globes. However, in practice contemporary consumption domes are also perfectly aware of the risk of "asphyxiating" the customer with atmospheric excess. Another gesture to the same aim is the temporary art exhibition that alludes to a different register and atmosphere - cultural rather than straightforwardly commercial (Fig. 4).

\footnotetext{
${ }^{6}$ Specifically, Albertsen (2012) employs the word "tonality" to describe how people in different roles interpret the same atmosphere differently.
} 


\section{(c) Mediating gestures - let me show you}

Retail spaces are meant for temporary guests, they are hosted, and as such they pacify us. This hosting is often dependent on inscription devices that direct our attention towards offers and affordances of the environment, but also to places and occasions outside of the situation itself. Atmospheres are mediated and in the end produced through these gestures and associations to other times and spaces: it is a game of subsequent engagement and disengagement. The retail space has an atmosphere, but this atmosphere includes the "presencing" of other atmospheres. Scents and colours might, for example, be meant to evoke an atmosphere of calmness and relate it to a certain brand. Albertsen has pointed out how even sheer gestures might convey atmospheres:

Rather than keeping an undistorted constant in different media, the key is the ability of the mediating chain to make the atmospheric present once again, not in the sense of re-presenting it exactly as it once was, but in the sense of presenting it "anew" (Albertsen, 2012:73).

The retail atmosphere thus relies on mediations and associations, where atmospheres - or rather hints, scents, and innuendos of atmospheres - are folded into each other. In fact, this task of mediating gestures is often delegated to the civilized consumers themselves. True, atmospheres are never within the control of a single actor, and urban atmospheric design always includes a set of relatively autonomous multiple actors. The atmospheres of shopping malls are thus also produced by materials and actors beyond the control of the retail managers and retail designers. One example are the smart phones, bags, clothes, etc. that people carry around, and which always point to places and occasions outside of the specific situation. One might however argue that these objects of trivial transitions are increasingly appropriated by retailers, through branded shopping bags and clothes with logos, club cards, websites, Instagram accounts, etc.

\section{(d) Dangerous proximities - "prisons are built with bricks of law" (Blake, 1975:xviii)}

The fourth component of atmo-management is perhaps more akin to a tactic than a strategy: it represents a collateral consequence of large-scale atmospheric production. Whether they like it or not, shopping malls might host or even produce dangerous proximities, where actors regarded as illegitimate by those who run the business keep reappearing (Fig. 5). Typically, malls have struggled with undisciplined gangs of youths, peddlers who populate the interstices inside or outside of the mall, but also "erratic" behaviour on the part of apparently legitimate customers. The sheer size of malls in conjunction with the often quite uninhabitable and vast infrastructures outside it, conjures up an environment of "pure

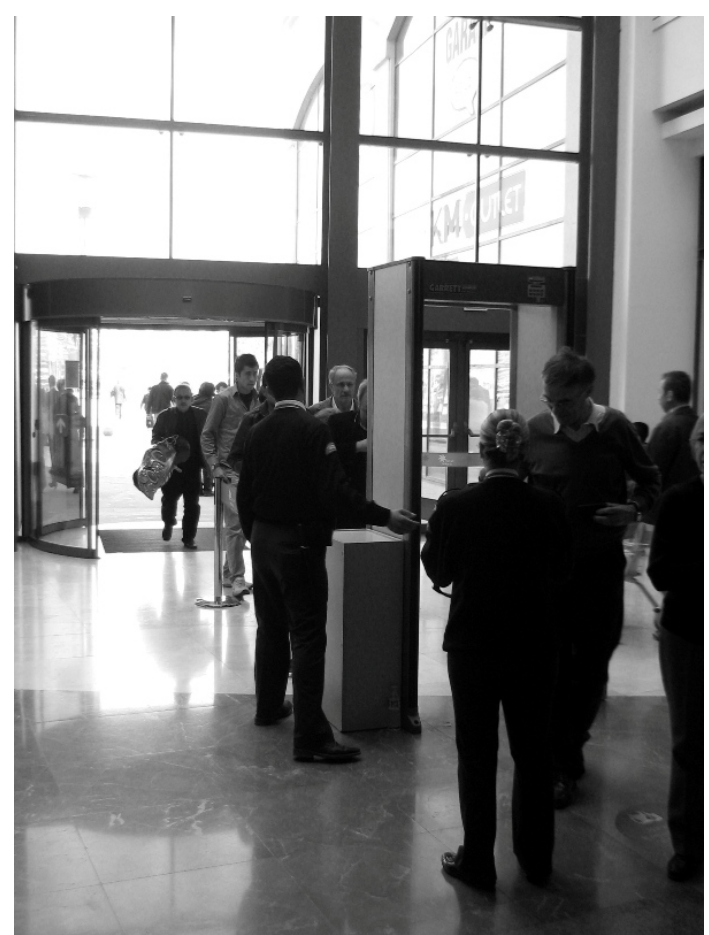

Figure 5. Security check at the entrance of Forum Ankara Outlet, Turkey (photo by author).

insides and dangerous outsides" (Franzén, 2001:206 pp.) but, there are always unintended consequences and it can often backfire when a space is kept pure. From this perspective, territoriology suggests that territorial borders are not just located at the perimeter of the territory, they are also written all over it. ${ }^{7}$ While retail depends on customers, retail environments both invite them to become more or less active part of their atmospheres, and set the limits of what is proper and acceptable, thus defining where rule breaking and violence begin. A politics of definition of actions and behaviours is at play.

Dangerous proximities also occur whenever a threatening atmosphere is created by panicked crowds spinning out of control, like in the wake of an upheaval, a major accident, or some kind of disaster. These are extreme cases where the smells and atmosphere of the crowding humans take part in the production of collective violence (Gandy, 2016:365). It might, however, also be through singular and individual yet serial instances of minor panic episodes, due to feelings of not belonging, stress or desperation, that the other to the civilized consumer - or, the other side of the civilized consumer itself - manifests. It is, in fact, important to remind us that retail and consumption-oriented open environments

\footnotetext{
${ }^{7}$ In short, territoriology might be defined as the science of territories and territorial production. We have developed this perspective in previous works (Kärrholm, 2007; Brighenti, 2010; Brighenti and Kärrholm, 2018).
} 
have turned out to be quite fragile. For instance, as spaces of symbolic value, they have been put "under aggression" (Hatuka, 2011) by recent terrorist actions. Malls are also sadly a known arena for autonomous perpetrators acting out of their desperation. Clearly, the target of violent attacks has been precisely the sense of security, comfort and relaxation that the spaces of civilized consumption were supposed to define in the first place. Terrorists and attackers, in other words, aim to have the general public wake up in a nightmare precisely where this same public used to - or imagined to - feel peacefully at "home".

\section{Civilized consumption and the domain of ascetic practicing}

George Ritzer has noted how retail spaces, not least in the US, have developed into cathedrals of consumption, suggesting that consumerism has become a kind of religion, and that ever larger shopping spaces bring enchantment and feelings of "celestial joy" to their audiences (Ritzer, 2005:7). Here we suggest that the sacredness of these domes might have to do with more than enchantment; it is, in fact, connected to rituals, disciplination and asceticism supported and encouraged by atmospheric design. Asceticism must be understood as the constant striving towards improvement by reducing and domesticating unwanted practices. In a nutshell, asceticism means practicing in order to ameliorate oneself, and while this tendency is evident in the religious sphere, several other domains now seem to function in a similar way. Following Sloterdijk's insight, then, consumption is not merely "erotic", not a sheer spur towards "enjoying oneself", but also connected to the pursuit of some sort of actual "improvement of the self":

Whoever wanted to change their life found themselves amidst an ever widening horizon of lifeaugmenting and life-increasing accessories - these are the strongest attractors in the modern deluge of commodities, which is often unjustly described only in terms of consumerism. Their acquisition is tied to a share in elevated fitness chances and expanded gratifications (Sloterdijk, 2013b:366).

From this perspective, consumerism, far from mere distraction and relaxation, entails focused effort. In his analysis of anthropotechnics, Sloterdijk is mostly interested in what we may call "specialized performances". These are situations where a specially trained subject - an acrobat or more generally, a gymnast or sportsman - acts as a kind of monstrous exemplar of their kind, highlighting which wonderful (or, alternatively, chilling) achievements can be attained through relentless, scrupulous training and the cultivation of the "strength of the will". However, the case of the consumer suggests that a similar process concerns not only specialists, but includes lay persons, too. To claim that there may be some "heroism" (or "supermanism") in consumption may at first look ridiculous, if not suspect. Celebrating the consumer is certainly not what we aim to do. Yet, the first thing to understand is that heroism is not intrinsically good, as usually held. The anthropotechnic perspective enables us to see that this specific type of heroic performance can only be obtained at the price of training, focus and discipline. As first illustrated by Foucault (1975), discipline does not simply operate from the outside of the subject, but inherently looks for its collaboration into subjection. For discipline to work, the subject must collaborate into entering or staying in a defined field of power relations. In contrast, the territory of asceticism and its disciplines may not be as immense as Sloterdijk depicts it. It may well turn out to be restrained: in fact, the simplified version of life that is propounded by asceticism corresponds to a reduction of the dimensions of experience. In practice, practicing means focusing on the quantitative improvement of a small number of variables in life. But, is this not precisely what is happening with shopping?

The training subject is one who, as Simmel first noticed, actively uses their brain as a protective organ, albeit in a very special way. In fact, the training subject acting under the ascetic imperative is particularly selective in absorbing the atmosphere, "open" to certain stimulations and "closed" to many others. Like von Uexküll's (1934) tick, the training consumer is selectively insensitive; but, differently from the tick, their insensitivity evolves in the direction of a sought after amelioration of oneself - a sense of "progress". If so, the hypothesis may be submitted that civilized consumption is a form of training in consumerism, and the territorialization of a specific role, lifestyle or even vocation. As seen above, capitalist consumption could not work without a concurrence of pacification and activation, and this is where asceticism can be grafted onto. While consumerism is usually described as a form of hedonism for those who can afford it, the contemporary atmoculture of shopping puts a lot of work on the shoulders of the consumer. As noticed, the consumer assumes upon its shoulders the task of mediating the gestures constituting the atmosphere. The stores are not there to provide the basic necessities, i.e. to respond to a given need, rather, they provide a specific milieu through which one can fully navigate only by taking an active part in it. Given the crucial role of atmospheres in the whole enterprise of mallification, this is not a minor contribution. For retail to work, the consumer must be disciplined, not simply in the classic sense of being civilized (pacifically lawabiding, accepting the structure of authority etc.), but also in the sense of actively turning the atmosphere designed for her/him into a factor of commercial choice, increased activity, and intensification of feelings. So, whereas shopping is usually depicted as distracted or even absent-minded behaviour, if we look at it as practicing, we notice it also entails a certain cultivation of the will. In this context, imitation (including, self-imitation) and rhythmic repetition play a crucial part in sustaining the ascetic effort. "Bettering one's 
shopping" may read as a strange expression, but perhaps it captures part of the reality of what is happening in the mall. Sharon Zukin (2004) has described the possibility of the increasingly skilled shopper to find strategies and bargains that seemingly allow for an identity building beyond the economical realities of the shopper. Other ways of actively engaging in one's shopping skills might be through the mobilization and collaboration with a personal shopper, through actively following or managing blogs and social media on the subject, or through learning how to consume in a more "sustainable" way (Hall, 2011; Fredriksson et al., 2017). It may not be a coincidence that edutainment retail - retail targeting children and teaching them both how to shop, and what to shop - is now becoming a quite widespread format. The role of the civilized and increasingly ascetic consumer can, when fully trained, be called upon or triggered through responsiveness, affordances and atmospheres. In short, there seems to be an increasing number of ways through which ascetic disciplination becomes inscribed or ingrained in the contemporary atmoculture of consumption. Most notably, such atmoculture does not always coincide with the legal scaffolding of retail spaces, with its urban design, or with its business scheme. An array of potential conflicts remains open between the practicing consumer and the managerial view on retail - so perhaps, the shopping mall awaits its own Antigone...

\section{Conclusions}

In this text we have investigated the production of atmospheres in shopping environments, and how this production seems to promote and sustain a type of behaviour known as civilized consumption. We have argued that the production of retail atmospheres can be analysed with reference to Sloterdijk's theorization of not only capitalist interiors, but also asceticism and the rise of a general training conscience. These two components seem to be parts of what we have called atmoculture. In conclusion, we may raise the question about which type of human being has been created by the atmospheres of the mall. The anthropotechnical process of consumer capitalism, as developed in dedicated domes, cannot, in our view, be examined without reference to the spreading of atmoculture and its disciplining traits. In this article, we have suggested four different aspects and modes of atmospheric production: immediate responsiveness, intensity through variation, mediating gestures and the role of absent yet bordering dangers. These all come with increasing requirements and demand on the consumer to actively and intensely experience and improve themselves in different ways, to translate atmospheres into personal desires and skills, to feel, smell and listen, while simultaneously being wrapped up in an atmosphere of comfort and safety (but where discomfort and fear sometimes lingers just behind the surface). Atmospheres are related to the affects and the intensities that move us, yet they are difficult to pinpoint down and mea- sure. They cannot be grasped or escaped or boxed in, but this is perhaps also why they often are so powerful. The specific atmosphere of the mall might aim to animate us in new and unforeseen ways. But, as it encourages us to improve a reduced set of skills, it sustains an always partial and disciplined animation. The territorialization of the societal role of the consumer could be explored further in this vein. It might not be that shopping malls have become our only temples, or that we are on a constant hunt for brands and shopping environments to act as our gurus; the role of a civilized consumer is of course but one of many possible human roles. As we visit the mall, we might fail to play the role of the civilized consumer, but we will for sure (in more or less subtle ways) be reminded of the role's existence. The more time we spend shopping, the larger and more inescapable these environments become, and the more they work through the hazy and tacit intensities of atmospheres and atmoculture, the more urgent it becomes to study and try to spell out the ethics, morals, techniques and reductions that seems to come with them. The civilized consumer might largely be a product of the mall, but its ascetic ideals will of course, for good and for bad, haunt other parts of our society as well. In fact, it remains to be investigated how atmoculture interacts with other more or less ascetical and territorialized societal roles - such as the dietist, the activist, the exerciser, etc. - following in the wake of our anthropotechnic era. ${ }^{8}$ These are roles through which we discipline and shape our bodies and selves, but also roles through which we come to play a part in the stabilization (or destabilization) of territories such as malls, shops, gyms and squares, that is, in the rewriting of contemporary urban space.

\section{Data availability. No data sets were used in this article.}

Competing interests. The authors declare that they have no conflict of interest.

Acknowledgements. We would like to thank Simon Runkel and Damien Masson for an interesting conversation that began at the Nordic Geography Meeting in Stockholm, 2017. We would also like to thank Rebecka Kärrholm for helping us with a field trip.

\section{Edited by: Benedikt Korf}

Reviewed by: two anonymous referees

\footnotetext{
${ }^{8}$ We acknowledge that a limitation of the present article lies in not elaborating more explicitly at the theoretical level on the link between atmospheres and the emergence of new societal roles. Limitations in space have led us to reserve this discussion for a future outlet.
} 


\section{References}

Akrich, M.: The De-scription of Technical Objects, in: Shaping Technology/Building Society: Studies in Sociotechnical Change, edited by: Bijker, W. E. and Law, J., MIT Press, Cambridge, MA, 205-224, 1992.

Albertsen, N.: Urbane atmosfærer, Sosiologi idag, 4, 5-29, 1999.

Albertsen, N.: Gesturing atmospheres, in: Ambiances in action/Ambiances en acte (s) - International Ambiances Network, International Congress on Ambiances, 2012, Montreal, 69-74, 2012.

Allen, J.: Ambient power: Berlin's Potsdamer Platz and the seductive logic of public spaces, Urban Studies, 43, 441-455, 2006.

Anderson, B.: Affective atmospheres, Emotion Space Soc., 2, 7781, 2009.

Asplund, J.: Det sociala livets elementära former, Korpen, Göteborg, 1987.

Bell, D.: The hospitable city: social relations in commercial spaces, Progr. Human Geogr., 31, 7-22, 2007.

Biehl-Missal, B. and Saren, M.: Atmospheres of Seduction: A Critique of Aesthetic Marketing Practices, J. Macromarket., 32, 168-180, 2012.

Bille, M., Bjerregaard, P., and Sørensen, T. F.: Staging atmospheres: Materiality, culture, and the texture of the in-between, Emotion Space Soc., 15, 31-38, 2015.

Blake, W.: The Marriage of Heaven and Hell, OUP, Oxford, 1975.

Böhme, G.: Atmosphere as the fundamental concept of a new aesthetics, Thesis Eleven, 36, 113-126, 1993.

Böhme, G.: Atmosphäre, Essays zur neuen Ästhetik, Suhrkamp, Frankfurt, 1995.

Borch, C.: Architectural Atmospheres: on the Experience and Politics of Architecture, de Gruyter, Berlin, 2014.

Brembeck, H., Hansson, N., and Vayre, J. S.: Life Phases, Mobility and Consumption: An Ethnography of Shopping Routes, Ashgate, Farnham, 2015.

Brighenti, A. M.: On territorology: Towards a general science of territory, Theory Cult. Soc., 27, 52-72, 2010.

Brighenti, A. M. and Kärrholm, M.: Animated Lands, University of Nebraska Press, Lincoln, in press, 2018.

Brighenti, A. M. and Pavoni, A.: Airspacing the City. Where Technophysics meets Atmoculture, Azimuth, 10, 91-103, 2017.

Cohen, D.: The Deadly Life of Logistics: Mapping Violence of Global Trade, University of Minnesota Press, Minneapolis, 2014.

Crawford, M.: The World in a Shopping Mall, in: Variations on a Theme Park, edited by: Sorokin, M., Hill and Wang, New York, 3-30, 1992.

Degen, M. M. and Rose, G.: The sensory experiencing of urban design: the role of walking and perceptual memory, Urban Studies, 49, 3271-3287, 2012.

Dovey, K.: Framing Places, Mediating Power in Built Form, Routledge, London, 1999.

Dufrenne, M.: Phénoménologie de l'expérience esthétique, Puf, Paris, 1953.

Erkip, F.: The rise of the shopping mall in Turkey: the use and appeal of a mall in Ankara, Cities, 22, 89-108, 2005.

Escher, A.: Die Atmosphäre des orientalischen Bazars, in: Die Alte Stadt. Vierteljahreszeitschrift für Stadtgeschichte, Stadtsoziologie, Denkmalpflege und Stadtentwicklung. Schwerpunkt: Stadt und Atmosphäre, Heft 2, edited by: Hasse, J., Franz Steiner Verlag, Stuttgart, 161-174, 2008.

Fiske, J.: Shopping for pleasure: Malls, power, and resistance, in: The Consumer Society Reader, edited by: Schor, J. B. and Holt, D. B., The Free Press, New York, 306-330, 2000.

Forty, A.: Words and Buildings: a Vocabulary of Modern Architecture, in: Vol. 268, Thames \& Hudson, London, 2000.

Foucault, M.: Surveiller et punir, Gallimard, Paris, 1975.

Franzén, M.: Urban Order and the Preventive Restructuring of Space: The Operation of Border Controls in Micro Space, Sociolog. Rev., 49, 202-218, 2001.

Fredriksson, C., Bäckström, K., Derwik, P., Fuentes, C., and Rhencrona, C.: Kunniga kunder ställer nya krav på handeln, Handelsrådet, Stockholm, 2017.

Gandy, M.: Urban atmospheres, Cult. Geogr., 24, 353-374, 2017.

Gehl, J. and Gemzöe, L.: Public space, public life, Arkitektens and Kunstakademiets Forlag, Copenhagen, 1996.

Gibbs, R.: Principles of Urban Retail Planning and Development, Wiley, Hoboken, 2012.

Gibson, J. J.:The Ecological Approach to Visual Perception, Psychology Press, New York, 1986.

Goss, J.: The "magic of the mall": an analysis of form, function, and meaning in the contemporary retail built environment, Ann. Assoc. Am. Geogr., 83, 18-47, 1996.

Hall, S. M.: Exploring the ethical everyday: An ethnography of the ethics of family consumption, Geoforum, 42, 627-637, 2011.

Hasse, J.: Kaufhausatmosphären, Architekt, 5-6, 39-42, 2004.

Hatuka, T.: Habitats under Contestation, lo Squaderno, 21, 17-20, 2011.

Healy, S.: Atmospheres of consumption: Shopping as involuntary vulnerability, Emotion Space Soc., 10, 35-43, 2014.

Julmi, C.: The Concept of Atmosphere in Management and Organization Studies, Organiz. Aesthet., 6, 4-30, 2016.

Kärrholm, M.: The materiality of territorial production: a conceptual discussion of territoriality, materiality, and the everyday life of public space, Space Cult., 10, 437-453, 2007.

Kärrholm, M.: The territorialisation of a pedestrian precinct in Malmö: Materialities in the commercialisation of public space, Urban Stud., 45, 1903-1924, 2008.

Kärrholm, M.: Retailising space: architecture, retail and the territorialisation of public space, Ashgate, London, 2012.

Kazig, R.: Einkaufsatmosphären: Ein wichtiges Kriterium für die Einkaufsstättenwahl, Cima-direkt, 1, 23-25, 2007.

Klingmann, A.: Brandscapes: Architecture in the Experience Economy, MIT Press, Cambridge, MA, 2007.

Kotler, P.: Atmospherics as a marketing tool, J. Retail., 49, 48-64, 1973.

Lofland, L. H.: The Public Realm. Exploring the City's Quintessential Social Territory, De Gruyter, New York, 1998.

Michon, R., Chebat, J. C., and Turley, L. W.: Mall atmospherics: the interaction effects of the mall environment on shopping behavior, J. Business Res., 58, 576-583, 2005.

Miles, S. and Miles, M.: Consuming Cities, Palgrave Macmillan, New York, 2004.

Monheim, R.: The role of pedestrian precincts in adapting city centres to new lifestyles, in: Sustainable Transport: Planning for Walking and Cycling in Urban Environments, Woodhead Publishing, Cambridge, 326-338, 2003. 
Nietzsche, F.: Unzeitgemässe Betrachtungen [Untimely Meditations], 1997 Edn., Cambridge University Press, Cambridge, 1876.

Nilsson, E.: Arkitekturen kroppslighet/Staden som terräng, LTH, Lund, 2010.

Ozuduru, B. H. and Guldmann, J. M.: Retail location and urban resilience: towards a new framework for retail policy. SAPI EN. S., Surv. Perspect. Integr. Environ. Soc., 6.1, 1-13, 2013.

Philippopoulos-Mihalopoulos, A.: Atmospheres of law: Senses, affects, lawscapes, Emotion Space Soc., 7, 35-44, 2013.

Philippopoulos-Mihalopoulos, A.: Milieu, Territory, Atmosphere: New Spaces of Knowledge, in: Knowledge-creating Milieus: Firms, Cities and Territories, edited by: PhilippopoulosMihalopoulos, A. and Cusinato, A., Springer, Berlin, Heidelberg, 79-95, 2015.

Philippopoulos-Mihalopoulos, A.: Withdrawing from atmosphere: An ontology of air partitioning and affective engineering, Environ. Plan. D, 34, 150-167, 2016.

Plöger, J.: Presence-experiences - the eventalisation of urban space, Environ. Plan. D, 28, 848-866, 2010.

Rabbiosi, C.: The invention of shopping tourism. The discursive repositioning of landscape in an Italian retail-led case, J. Tourism Cult. Change, 9, 70-86, 2011.

Ranasinghe, P.: Consumption, Public Disorder and the Politics of Knowing, lo Squaderno, 19, 19-22, 2011.

Ritzer, G.: Enchanting a Disenchanted World: Revolutionizing the Means of Consumption, Pine Forge Press, Thousand Oaks, 2005.

Runkel, S.: Zur Genealogie des Atmosphären-Begriffs. Eine kritische Würdigung der Ansätze von Hermann Schmitz und Gernot Böhme, in: Atmosphären des Populären II. Perspektiven, Projekte, Protokolle, Performances, Personen, Posen, edited by: Wünsch, U., Uni-Edition, Berlin, 20-39, 2016.

Serres, M.: The Natural Contract, University of Michigan Press, Ann Arbor, 1995.

Sharma, A. and Stafford, T. F.: The Effect of Retail Atmospherics on Customers' Perceptions of Salespeople and Customer Persuasion: An Empirical Investigation, J. Business Res., 49, 183-191, 2000.

Shields, R. (Ed.): Lifestyle shopping: The subject of consumption, Routledge, London, 2003.
Simmel, G.: Die Großstädte und das Geistesleben [The Metropolis and Mental Life], in: The Sociology of Georg Simmel, edited by: Wolff, K. H., The Free Press, Glencoe, IL, 1903.

Sloterdijk, P.: Atmospheric politics, in: Making Things Public, Atmospheres of Democracy, edited by: Latour, B. and Weibel, P., The MIT Press, Cambridge, MA, and ZKM, Karlsruhe, 2005.

Sloterdijk, P.: Bubbles: Spheres Volume I: Microspherology, translated by: Hoban, W., Semiotext(e), Los Angeles, 2011.

Sloterdijk, P.: In the World Interior of Capital: Towards a Philosophical Theory of Globalization, Polity Press, Cambridge, MA 2013a.

Sloterdijk, P.: You must Change your Life, translated by: Hoban, W., Polity Press, Cambridge, MA, 2013b.

Sloterdijk, P.: Globes: Spheres Volume II: Macrospherology, translated by: Hoban, W., Semiotext(e), Los Angeles, 2014.

Sloterdijk, P.: Foams: Spheres Volume III: Plural Spherology, translated by: Hoban, W., Semiotext(e), Los Angeles, 2016.

Staeheli, L. A. and Mitchell, D.: USA's destiny? Regulating space and creating community in American shopping malls, Urban Studies, 43, 977-992, 2006.

Stillerman, J. and Salcedo, R.: Transposing the urban to the mall: routes, relationships, and resistance in two Santiago, Chile, shopping centers, J. Contemp. Ethnogr., 41, 309-336, 2012.

Thrift, N.: Different atmospheres: of Sloterdijk, China, and site, Environ. Plan. D, 27, 119-138, 2009.

Turley, L. W. and Milliman, R. E.: Atmospheric effects on shopping behavior: a review of the experimental evidence, J. Business Res., 49, 193-211, 2000.

Vernet, D. and de Wit, L. (Eds.): Boutiques and Other Retail Spaces. The Architecture of seduction, Routledge, New York, 2007.

von Uexküll, J.: Streifzüge durch die Umwelten von Tieren und Menschen: Ein Bilderbuch unsichtbarer Welten, Springer, Berlin, 1934.

Wikström, T.: The Responsive City, available at: http: //tomaswikstrom.nu/drupal/node/18 (last access: 22 May 2017), 2009.

Wolff, J.: The invisible flâneuse. Women and the literature of modernity, Theory Cult. Soc., 2, 37-46, 1985.

Zukin, S.: Point of Purchase: How Shopping changed American Culture, Psychology Press, New York, 2004.

Zumthor, P.: Atmosphere, Birkhauser, Basel, 2006. 